\title{
THE ROLE OF ORGANIC MATTER ON IMPROVEMENT OF THE PROPERTIES OF KUSAMBA BEACH SAND SOIL, DAWAN SUB-DISTRICT, KLUNGKUNG REGENCY, BALI FOR WATERMELON (Citrullus lanatus Tunb) CULTIVATION
}

\author{
Wiyanti*, Ni Nengah Soniari, and I Nyoman Dibia \\ Program Study of Agroecotechnology, Faculty of Agriculture, Udayana University, Indonesia \\ *Corresponding author: wiyanthi@unud.com
}

\begin{abstract}
The study on The Role of Organic Matter on Improvement of The Properties of Kusamba Beach Sand Soil, Dawan Sub-District, Klungkung Regency, Bali For Watermelon (Citrullus lanatus Tunb) Cultivation was conducted in the green house of Agriculture Faculty, Udayana University, Bali. The aim of this study was to determine the role of organic matter in the soil properties of beach sand (Entisol type) to increase crop productivity of watermelon. The research used pot experiment with completely randomized design (CRD) method. The treatments used was organic fertilizer of waste cattle with base fertilizer $(\mathrm{N}, \mathrm{P}, \mathrm{K})$. The dosage of organic fertilizer were: $\mathrm{P}_{0}\left(20 \%\right.$ of the weight of soil); $\mathrm{P}_{1}(40 \%) ; \mathrm{P}_{2}(60 \%)$, and $\mathrm{P}_{3}(80 \%)$. Each treatment was repeated three times, so in total were 12 pots treatment. Organic matter can decrease bulk density, soil permeability, and increase the total porosity of the soil. It was also able to increase total nitrogen, availability $\mathrm{P}$ in soil, dry weight of crop and the weight of the fruit at harvest. The highest bulk density was at $\mathrm{P}_{0}$ and the lowest was at $\mathrm{P}_{3}$ or decreased by $23.17 \%$. The soil porosity increased by $7.98 \%$, while the soil permeability decreased by $26.29 \%$. The highest of total Nitrogen and $\mathrm{P}$ availability at treatment $\mathrm{P}_{3}$ which increased by $100 \%$ and $135.33 \%$ repectively when compared with $\mathrm{P}_{0}$. The dry weight of crop and weight of fruit at harvest increased of $48.81 \%$ and $97.70 \%$ when compared with treatment of $\mathrm{P}_{0}$.
\end{abstract}

Keywords: organic matter, sand beach soil, soil properties, water melon cultivation

\section{INTRODUCTION}

The coastal area in Kusamba Village, Klungkung, Bali is utilized as salt field by local community. Salt mining usually can be done during the dry season, while in the rainy season the community does not have a permanent job. To support their needs, the community can utilize sandy land in this area to grow crops. Sandy land is generally less productive land, so it needs to be treated to increase its productivity as a growing medium for agricultural crops, especially in the rainy season.

The soil in this region is the Entisol order, suborder psamments which have rock fragments and texture of fine or coarse sand of less than $35 \%$ (by volume) in all layers. This type of soil includes young and undeveloped soil, with loose or single structure, rapid permeability and infiltration up to very fast, and low organic matter content. According to Hardjowigeno (1995), the Entisol is a very young soil that is just the 
THE ROLE OF ORGANIC MATTER ON IMPROVEMENT OF THE PROPERTIES OF KUSAMBA BEACH SAND SOIL, DAWAN SUB-DISTRICT, KLUNGKUNG REGENCY, BALI FOR WATERMELON (Citrullus lanatus Tunb) CULTIVATION Wiyanti, Ni Nengah Soniari, and I Nyoman Dibia

beginning level of its development, there is no other founding horizon except epipedon ochrik, albik or histik. Santoso (1993) said that the Entisol land is formed from river deposits (alluvial that have discontinuity soil formed because it has no relation to each other), therefore the organic carbon is low. Darmawijaya (1990) said that Entisol soil generally contains enough $\mathrm{P}$ and $\mathrm{K}$ which is still fresh, but not yet sufficiently available for the plant. Rapid permeability and infiltration and the low content of organic matter cause other elements to be easily washed and the water holding capasity is very low. To increase the productivity it is necessary to improve the main limiting factor, which is very low water holding capasity (sand texture) by the addition of organic matter.

Organic matter have an important role in improving the soil properties of both physical, chemical and biological properties. According to Sisworo (2006) in Pirngadi (2009), organic matter is a source of carbon, source of nutrients and energy to support the life and breeding of various types of microbes in the soil. Microbial is a very important factor in the process of decomposition of organic matter in the soil. It is also influential in the process of forming soil structure or aggregation of land either directly or indirectly. A good soil structure will cause the soil aeration to be ideal for air and water traffic processes and water holding capacity increases, so that the water will not just lost and can be available in a relatively long time for the plants. Organic matter is capable of providing complete nutrients both micro and macro elements although the number is relatively low, so in practice must be balanced with the use of inorganic fertilizers.

According to research by Dahlan et al. (2008), the treatment of horse manure combined with $\mathrm{N}, \mathrm{P}$, and $\mathrm{K}$ fertilizers significantly affected changes in soil properties, namely moisture content, organic $\mathrm{C}$ content, $\mathrm{pH}$, and $\mathrm{P}$ availability in soil. It increased the levels of $\mathrm{P}$ in soil along with elevated moisture content and soil $\mathrm{pH}$, but $\mathrm{C}$ organic content decreased. The highest available P-level was obtained in the combination of application of manure application 15 tons ha-1 and NPK fertilizer $300 \mathrm{kgs}$ ha-1 with an incubation period of 14 days. Meanwhile, according to research by Chusnul Agustina (2007), composting at a dosage of 30 tons ha-1 had the best effect on improving some soil physical properties, namely being able to reduce bulk density, particle density, and rapid drainage pores. It was also able to increase the total porosity of soil, slow drainage pore and available pore water and aggregate stability. According to research by Wiyanti and Arya (2008), the use of a combination of $10 \%$ shisako organic 
fertilizer (1.2 tons $\mathrm{ha}^{-1}$ and 90\% urea (360 tons $\mathrm{ha}^{-1}$ ) provided the hightest yield of milled dry grain, which is 7.0 tons $\mathrm{ha}^{-1}$ and not significantly different from the treatment of $70 \%$ shisako fertilizer (8.4 tons $\mathrm{ha}^{-1}$ ) combined with $30 \%$ urea fertilizer $(120 \mathrm{~kg}$ $\mathrm{ha}^{-1}$ ), amounting to 6.2 tons $\mathrm{ha}^{-1}$.

Based on the above description, the authors conducted a study using pot experiment entitled: "The Role of Organic Matter on the Improvement of the Property of Kusamba Beach Sand Soil, Dawan Subdistrict, Klungkung Regency, bali for Watermelon Cultivation, which is a salt field. The purpose of this study is to determine the role of organic matter to increase the productivity of beach sand as a medium of growing watermelon plants. Thus in the rainy season salt farmers can still produce through agricultural cultivation activities by utilizing the land around its salt fields. It is expected that that organic materials can increase the productivity of sand soil, so as to increase the production of watermelon plants in Kusamba, Klungkung, Bali and eventually can increase salt farmer income in this region.

\section{MATERIALS AND METHODS}

The design used in this study was Completely Randomized Design (RAL) with one main treatment factor. The treatment was organic fertilizer from cow dung with 4 levels of treatment, namely $20 \%$ of the weight of soil as control (P0), $40 \%$ by weight of soil (P1), $60 \%$ by weight of soil (P2), and $80 \%$ by weight of soil (P3) . Each treatment was repeated 3 times, so that 12 pots were obtained. To increase the availability of nutrients in the soil, pelangi inorganic fertilizer was added with a dose of $400 \mathrm{kgs}$ $\mathrm{ha}^{-1}$. Parameters/soil characteristics observed included texture, bulk density, particle density, moisture content, total porosity, permeability, nitrogen $(\mathrm{N})$, phosphorus $(\mathrm{P})$, potassium $(\mathrm{K}), \mathrm{pH}$, organic matter, and soil salinity. The effects of the treatment were evaluated by measuring the weight of crop and weight of fresh fruit.

Soil analysis methods used were: texture with pipette method, bulk density with ring sample method, particle density with pycnometer, water content with gravimetric method, permeability with Constan Head Permeameter method and total porosity calculated using formula (1 - Bulk density/particle density) x 100\% . The parameters of chemical properties were analyzed by : $\mathrm{N}$ with Kjeldahl method, $\mathrm{P}$ and $\mathrm{K}$ with Bray I method, $\mathrm{pH}$ with $\mathrm{pH}$-meter, organic matter with Walkey \& Black method, and salt content with Electric Conductometer.

The materials used in this study include: chemicals for soil analysis, Entisol soil/sand soil, manure, and pelangi fertilizer. 
THE ROLE OF ORGANIC MATTER ON IMPROVEMENT OF THE PROPERTIES OF KUSAMBA BEACH SAND SOIL, DAWAN SUB-DISTRICT, KLUNGKUNG REGENCY, BALI FOR WATERMELON (Citrullus lanatus Tunb) CULTIVATION Wiyanti, Ni Nengah Soniari, and I Nyoman Dibia

While the tools used are: buckets for planting pots, ovens, scales, and other tools for soil analysis.

Before planting, organic fertilizer is mixed with soil according to the dosage. Planting was carried out after 2 weeks old seeds and each pots was planted 2 plants. After 1 month old thinning was carried out and 1 plant was left. During plant growth, maintenance is carried out such as watering, spraying, and fertilizing. Harvesting was done at around 3 months after planting. The fresh fruit was weighed and soil samples are taken to be analyzed in the laboratory.

The data were analyzed statistically using variance (anova) to determine the effect of the treatment. When there was a real difference between treatments, it will be followed by the smallest real difference test with a confidence level of $5 \%$.

\section{RESULTS AND DISCUSSION}

\section{Research result}

Based on the result of variance analysis, it was found that giving of cow dung organic matter had significant effect in almost all parameters observed except soil $\mathrm{pH}$. The complete significance of the effect of organic matter on soil properties and watermelon yields is presented in Table 1.

Table 1. Significance of effects of organic matter on parameters observed

\begin{tabular}{clc}
\hline No. & \multicolumn{1}{c}{ Parameters } & Significance \\
\hline $\mathbf{1}$ & \multicolumn{1}{c}{$\mathbf{2}$} & $\mathbf{3}$ \\
\hline 1 & Bulk density $\left(\right.$ grams $\left.\mathrm{cm}^{-3}\right)$ & $* *$ \\
2 & Total porosity $(\%)$ & $* *$ \\
3 & Soil permeability $\left(\mathrm{cm}^{3} \mathrm{hour}^{-1}\right)$ & $* *$ \\
4 & Soil nitrogen total $(\%)$ & $* *$ \\
5 & Soil available phosphor $(\mathrm{ppm})$ & $* *$ \\
6 & Soil organic matter $(\%)$ & $*$ \\
7 & Salinity $\left(\right.$ Electric condictivity/EC) $\left(\mathrm{mmhos} \mathrm{cm}^{-1}\right)$ & $* *$ \\
8 & Soil pH & $\mathrm{ns}$ \\
9 & Dry weight of crop $\left(\mathrm{grams} \mathrm{pot}^{-1}\right)$ & $*$ \\
10 & Fresh fruit weight $\left(\right.$ grams pot $\left.^{-1}\right)$ & $* *$ \\
\hline
\end{tabular}

Description: $\mathrm{ns}=$ non significant

$*$ = significant different $(\mathrm{P}<0.05)$

$* *$ = very significant different $(\mathrm{P}<0.01)$

\section{Soil bulk density}

The soil bulk density is the ratio between the dry weight of the soil and the total volume of soil. The results of statistical analysis showed that organic fertilizer had a significant effect on the bulk density. 
Organic matter can reduce the bulk density, the highest bulk density was in the treatment of $\mathrm{P}_{0}\left(1.325\right.$ grams $\left.\mathrm{cm}^{-3}\right)$, then decreased successively, namely $\mathrm{P}_{1}\left(1.218\right.$ grams $\left.\mathrm{cm}^{-3}\right)$, $\mathrm{P}_{2} \quad\left(1.197\right.$ gram $\left.\mathrm{cm}^{-3}\right)$, and lowest at treatment $\mathrm{P}_{3}\left(1.018\right.$ gram cm $\left.\mathrm{cm}^{-3}\right)$ (Table 2).

\section{Soil total porosity}

The total porosity is the ratio of the pore space volume to the total volume of soil or can be calculated by the formula (1-bulk density/particle density) x 100\%. Based on the results of statistical analysis it turns out that the provision of organic matter can significantly increase the total porosity of the soil. The lowest bulk density occurred in treatment $\mathrm{P} 0$, that was equal to $58.4509 \%$ and highest at treatment $\mathrm{P} 3$ equal to $63.1158 \%$ (Table 2).

\section{Soil permeability}

Soil permeabilty are the ability of the soil to pass water per unit time. The result of statistical analysis showed that the giving of organic matter gave a very significant different effect to the soil permeability. Organic matter was able to decrease soil permeability. The highest permeability of soil was found in treatment $\mathrm{P}_{0}\left(205.733 \mathrm{~cm} \mathrm{~h}^{-}\right.$ ${ }^{1}$ ) and lowest at treatment $\mathrm{P}_{3}\left(151.643 \mathrm{~cm} \mathrm{~h}^{-1}\right)$ (Table 2).

Table 2. Effect of organic matterl on bulk density, total porosity and soil permeability

\begin{tabular}{cccr}
\hline \multirow{2}{*}{ Treatments } & \multicolumn{4}{c}{ Parameters } \\
\cline { 2 - 4 } & $\begin{array}{c}\text { Bulk density } \\
\left(\text { grams cm }^{-2}\right)\end{array}$ & Total porosity $\mathbf{\%})$ & $\begin{array}{c}\text { Soil permeability } \\
\left(\mathbf{c m ~ h}^{-1}\right)\end{array}$ \\
\hline $\mathbf{1}$ & $\mathbf{2}$ & $\mathbf{3}$ & $\mathbf{4}$ \\
\hline $\mathrm{P}_{0}$ & $1,325 \mathrm{~d}$ & $58,4509 \mathrm{a}$ & $205.733 \mathrm{~d}$ \\
$\mathrm{P}_{1}$ & $1.218 \mathrm{c}$ & $61.1857 \mathrm{~b}$ & $141.048 \mathrm{a}$ \\
$\mathrm{P}_{2}$ & $1.197 \mathrm{~b}$ & $60.4817 \mathrm{c}$ & $153.775 \mathrm{cb}$ \\
$\mathrm{P}_{3}$ & $1.018 \mathrm{a}$ & $63.1158 \mathrm{~d}$ & $151.643 \mathrm{~b}$ \\
\hline BNT 5\% & 0.009176 & 0.003074 & 205.733 \\
\hline
\end{tabular}

Description: - the number followed by the same letter means no significant difference - numbers followed by unequal letters mean significant differences

\section{Soil nitrogen total (total $N$ )}

The giving of organic matter resulted in a very significant different to the total $\mathrm{N}$ of the soil. The lowest total $\mathrm{N}$ was in treatment $\mathrm{P}_{0} \quad(0.04 \%)$ then increased significantly in the treatment of $\mathrm{P}_{2} \quad(0.06 \%)$ and the highest was in treatment $\mathrm{P}_{3}(0.08 \%)$ (Table 3).

\section{Soil phosphor availability (available}

P)

The provision of organic matter has a very significant different effect on P-availability in soil (Table 3). The lowest available $\mathrm{P}$ value achieved at $\mathrm{P} 3$ treatment (301.8 ppm) and it was significantly different from that of $\mathrm{P}_{0}, \mathrm{P}_{1}$ and $\mathrm{P}_{2}$. 
THE ROLE OF ORGANIC MATTER ON IMPROVEMENT OF THE PROPERTIES OF KUSAMBA BEACH SAND SOIL, DAWAN SUB-DISTRICT, KLUNGKUNG REGENCY, BALI FOR WATERMELON (Citrullus lanatus Tunb) CULTIVATION Wiyanti, Ni Nengah Soniari, and I Nyoman Dibia

Table 3. Effect of organic matter on total N, available P, organic matter, EC, and soil pH

\begin{tabular}{lcccrr}
\hline Treatment & \multicolumn{5}{c}{ Parameters } \\
\cline { 2 - 6 } & $\begin{array}{c}\text { Soil total } \\
\text { nitrogen } \\
(\%)\end{array}$ & $\begin{array}{c}\text { Soil } \\
\text { Availale } \mathbf{P} \\
(\mathbf{p p m})\end{array}$ & $\begin{array}{c}\text { Soil organik } \\
\text { matter }(\%)\end{array}$ & $\begin{array}{c}\text { Soil EC } \\
\left(\mathbf{m m h o s} \mathbf{~ c m}^{-1}\right)\end{array}$ & Soil pH \\
\hline $\mathrm{P}_{0}$ & $0.04 \mathrm{a}$ & $372.67 \mathrm{~b}$ & $2.83 \mathrm{dc}$ & $1.6 \mathrm{c}$ & $6.9 \mathrm{~b}$ \\
$\mathrm{P}_{1}$ & $0.04 \mathrm{a}$ & $370.49 \mathrm{~b}$ & $3.79 \mathrm{cb}$ & $2.09 \mathrm{~d}$ & $6.9 \mathrm{~b}$ \\
$\mathrm{P}_{2}$ & $0.06 \mathrm{~b}$ & $402.36 \mathrm{a}$ & $4.72 \mathrm{~b}$ & $1.42 \mathrm{~b}$ & $6.8 \mathrm{a}$ \\
$\mathrm{P}_{3}$ & $0.08 \mathrm{c}$ & $402.25 \mathrm{a}$ & $6.66 \mathrm{a}$ & $1.29 \mathrm{a}$ & $6.9 \mathrm{~b}$ \\
\hline BNT 5\% & 0.0058 & 2.35001 & 1.589649 & 1.098955 & 0.0999 \\
\hline
\end{tabular}

Description: - the number followed by the same letter means no significant difference - numbers followed by unequal letters mean significant differences

\section{Soil organic matter}

Based on the results of statistical analysis it was found that the giving of organic matter had a very significant different effect on soil organic matter (Table 3.). The lowest organic matter was achieved in treatment $\mathrm{P}_{0}(2.83 \%)$, then increased in a row and showed significant differences starting from treatment $\mathrm{P}_{2}(4.72 \%)$ and the highest was in treatment $\mathrm{P}_{3}(6.66 \%)$.

\section{Soil pH and Electric conductivity (EC)}

The giving of organic matter gave non significant effect to soil $\mathrm{pH}$ and significant different effect to electric conductivity (Table 3). In general, it could be said that the organic matter was able to decrease the soil electric conductivity. It was proven that the highest electric conductivity was in treatment $\mathrm{P}_{1}\left(2.09\right.$ mmhos $\left.\mathrm{cm}^{-1}\right)$ then decreased significantly in treatment $\mathrm{P}_{2}(1.42$ mmhos $\mathrm{cm}^{-1}$ ) and the lowest was in treatment $\mathrm{P}_{3}\left(1.29\right.$ mmhos $\left.\mathrm{cm}^{-1}\right)$.

\section{Crop dry weight dan Fresh fruit weight}

Based on the statistical analysis it can be seen that the organic matter treatment resulted ingave a very significant different effect on the parameters of crop dry oven weight and fresh fruit weight (Table 4). Provision of organic matter could increase the crop dry weight and fresh fruit weight. The lowest weight was at treatment $\mathrm{P}_{0}(35.83$ grams $\operatorname{pot}^{-1}$ ), then increased not significantly at treatment of $\mathrm{P}_{1}\left(37.41\right.$ grams pot $\left.^{-1}\right)$, then increased significantly on treatment of $\mathrm{P}_{2}$ (45.63 grams pot ${ }^{-1}$ ) and $\mathrm{P}_{3}$ (53.32 grams pot ${ }^{1}$ ), but between $\mathrm{P}_{2}$ and $\mathrm{P}_{3}$ the result were not significantly different. While the weight of fruit during harvest increased along with increasing the dose of organic matter, although between treatments $\mathrm{P}_{1}, \mathrm{P}_{2}$, and $\mathrm{P}_{3}$ the increase were not significantly different. The lowest fruit yield was found in treatment $\mathrm{P}_{0}\left(747.8\right.$ grams pot $\left.^{-1}\right)$ and the highest was 
achieved at treatment $\mathrm{P}_{3}(1478.43$ grams

$\left.\operatorname{pot}^{1}\right)$.

Table 4. The effect of organic matter on dry crop weight and weight of fresh fruit

\begin{tabular}{|c|c|c|}
\hline \multirow[b]{2}{*}{ Perlakuan } & \multicolumn{2}{|c|}{ Parameters } \\
\hline & $\begin{array}{l}\text { Dry oven crop weight } \\
\left.\text { (grams pot }^{-1}\right)\end{array}$ & $\begin{array}{c}\text { Weight of fresh Fruit } \\
\left.\text { (grams pot }^{-1}\right)\end{array}$ \\
\hline 1 & 2 & 3 \\
\hline $\mathrm{P}_{0}$ & $35.83 a$ & $747.8 \mathrm{a}$ \\
\hline $\mathrm{P}_{1}$ & $37.41 \mathrm{ab}$ & $1469.6 \mathrm{~b}$ \\
\hline $\mathrm{P}_{2}$ & $45.63 \mathrm{bc}$ & $1343.47 \mathrm{~b}$ \\
\hline $\mathrm{P}_{3}$ & $53.32 \mathrm{c}$ & $1478.43 \mathrm{~b}$ \\
\hline BNT 5\% & 8.946567 & 138.4788 \\
\hline
\end{tabular}

Description: - the number followed by the same letter means no significant difference - numbers followed by unequal letters mean real differences

\section{Discussion}

Based on Table 1 and Table 2 it can be seen that the treatment of organic matter in various doses significantly affected the bulk density, total porosity of soil, and soil permeability. Provision of organic matter could reduce the bulk density, soil permeability, and increase the total porosity of the soil. This is because organic matter is a cement material that can improve soil aggregate. Sand soil was previously structured or arranged adjacently that causes high bulk density. The addition of organic matter will encourage soil aggregation, so that soil aggregates will be formed which can cause the weight of the bulk density to decrease. This is in accordance with Utomo (1985), that sand soil usually has a high bulk density and soil that contained high organic matter has a low bulk density. Thus it will also affect the other soil physical properties, such as increasing the total porosity of the soil and reducing soil permeability. The decrease in soil permeability is caused by the nature of organic matter which is able to absorb water besides to improving soil structure, so that the water holding capacity becomes increased and consequently the ability of the soil to pass water to decrease.

Table 3 and Table 4 show that the treatment of doses of organic matter has a significant different effect on the total $\mathrm{N}$ content, $\mathrm{P}$ availability, and organic matter after harvest, as well as the weighti of crop and production of watermelon. Organic matter is able to increase soil organic matter content, total nitrogen, available soil $\mathrm{P}$, crop dry weight, and fresh fruit weight

The giving of organic matter at $\mathrm{P}_{0}$ had significantly different effect with $\mathrm{P}_{1}, \mathrm{P}_{2}$, and $\mathrm{P}_{3}$ treatments on fresh fruit production. However, between treatments $\mathrm{P}_{1}, \mathrm{P}_{2}$, and $\mathrm{P}_{3}$ 
did not show any significant difference. The increase in the production of fresh fruit was due to the increased supply of organic matter on the Kusamba beach sand. The increase in fresh fruit production begun to be evident from doses of $\mathrm{P}_{1}\left(40 \%\right.$ organic matter) to $\mathrm{P}_{3}$ (80\% organic matter). This was due to the important role of organic matter in the sand soil that has bad physical properties and poor of nutrient. By adding organic matter, it can improve soil structure (improve soil aggregation); increase the absorption and water holding capacity of the soil so that the soil ability to provide water for the better so that the soil moisture will be more awake. Organic matter can also improve biological life in the soil, because the organic matter can be source of nutrient for microba; and as a nutrient source for plants (containing essential nutrients that are complete of both macro nutrients and micro elements). In addition organic matter can increase cation exchange capacity so that the ability to bind cations is higher so that nutrients are not easily washed/lost ( Mahdi et al., 2010 and Anon, 1984). Furthermore it was said that organic matter could improve soil permeability, namely reducing permeability in soils with coarse texture (sandy), organic matter could increase buffering capacity against drastic changes in soil properties, and increase the nutrient uptake efficiency for the crop so with the availability of nutrients sufficient in the soil there will be increased productivity of the plant.

The occurrence of increased crop dry weight with the increased of organic matter showed that there was an increase in the vegetative growth of plants. Optimal vegetative plant growth will also affect the growth of generative plants, especially in the forming of flowers and fruit.

Based on the results of soil analysis after harvest, there appears an increase in total $\mathrm{N}$, available $\mathrm{P}$, and organic matter in the presence of increasing doses of organic matter. Given the availability of $\mathrm{N}$ and $\mathrm{P}$ in the soil, more and more $\mathrm{N}$ and $\mathrm{P}$ are absorbed by plants. It is known that the most important function of $\mathrm{N}$ for plants is in the formation of proteins, and besides that the $\mathrm{N}$ element is also an integral part of chlorophyll (Anon, 1984). In addition to the adequacy of $\mathrm{N}$ elements, the adequacy of available $\mathrm{P}$ in the soil also has an effect on crop productivity. Tisdale et al. (1985) said that $\mathrm{P}$ element is considered as the key of life because this element is essential for both vegetative and generative phase such as: function in the translocation of plant nutrients, the formation of plant roots, the formation of flowers, fruits, etc.

Increasing doses of organic matter has a significant different effect on increasing the amount of soil organic matter after harvest. There was a tendency of the increase of soil 
organic matter content after harvest from $\mathrm{P}_{0}$ to $\mathrm{P}_{3}$. This is probably due to the organic matter that has been given has not been completely decomposed and utilized by the plant. This means there is an opportunity to be utilized in the next planting, without the need for additional organic ingredients.

\section{CONCLUSIONS}

The treatment of organic matter gives a significant different to all parameters observed in both soil and plant parameters, except the $\mathrm{pH}$ of soil. Organic matter can reduce the soil bulk density, soil permeability, and increase total soil porosity. The highest bulk density at treatment $\mathrm{P}_{0}$ and the lowest at treatment $\mathrm{P}_{3}$ or decreased by $23.17 \%$, lowest porosity of soil at treatment $\mathrm{P}_{0}(58.45 \%)$ and highest at treatment $\mathrm{P}_{3}$ $(63.12 \%)$ or increased equal to $7.98 \%$ while the highest soil permeability was in treatment $\mathrm{P}_{0}\left(205.73 \mathrm{~cm} \mathrm{hour}^{-1}\right)$ and the lowest was in treatment $\mathrm{P}_{3} \quad\left(151.643 \mathrm{~cm}\right.$ hour $\left.^{-1}\right)$ or decreased by $26.29 \%$. Organic matter able to increase the soil organic matter content, total $\mathrm{N}$, and soil available $\mathrm{P}$, dry oven crop weight, and watermelon fruit weight. The highest total nitrogen and soil organic matter was achieved in the $\mathrm{P}_{3}$ treatment, which was $0.08 \%$ and $6.66 \%$, respectively increasing by $100 \%$ and $135.33 \%$ when compared to $\mathrm{P}_{0}$ $(0.04 \%$ and $2.83 \%)$. The highest dry oven of crop weight and fruit was achieved in $\mathrm{P}_{3}$ treatment, each of 53.3 grams pot $^{-1}$ and 1343.47 grams pot $^{-1}$, or increased by $48.81 \%$ and $97.70 \%$ when compared to treatment $\mathrm{P}_{0}$ (35.83 gram pot ${ }^{-1}$ and 747.8 gram pot $^{-1}$ )

\section{ACKNOWLEGMENTS}

The author would like to thank the Institute of Research and Community Service of Udayana University for providing financial support in this study with the contract number: No. 237-53 / UN14.2 / PNL.01.03.00 / 2014 May 14, 2014.

\section{REFERENCES}

Anonim. (1984). Fertilizer and Plant Nutrition Guide. FAO. Rome. 1976 h. Buringh, P. (1993). Pengantar Pengajian Tanah-Tanah Wilayah Tropika dan Subtropika. Tranaslated by: Tejoyuwono Notohadiprawiro Agriculture Fakulty of Gadjah Mada University, Gadjah mada University Press.

Chusnul Agustina. (2007). Pengaruh Pemberian Kompos Terhadap beberapa Sifat Fisik Entisol serta Pertumbuhan Tanaman Jagung (Zea mays L). Essay. Agriculture Fakulty of Brawidjaya University, Malang.

Darmawijaya, M. I. (1990). Klasifikasi Tanah. Dasar Teori bagi Peneliti Tanah dan Pelaksana Pertanian di Indonesia. Gadjah Mada University Press, Yogyakarta.

Dahlan, M., Mulyati and Ni Wayan Dwiani, D. (2008). Studi Aplikasi Pupuk Organik dan Anorganik terhadap Perubahan Beberapa Sifat Tanah Entisol. Agroteksos, 3(18), 1-3.

Hardjowigeno. (1995). Ilmu Tanah. Akademika Presindo, Jakarta.

Mahdi, S. S., Hassan, G. I., Samoon, S. A., Rather, H. A., Dar, S. A., \& Zehra, B. 
(2010). Biofertilizers in Organic Agricultural. Journal Physiol, 2 (10), 42-54.

Pirngadi, K. (2009). Peran Bahan organik dalam Peningkatan Produksi Padi Berkelanjutan Mendukung Ketahanan Pangan Berkelanjutan. Pengembangan Inovasi Pertanian 2 (1), 48-64.

Santoso. (1993). Sifat Dan Ciri Tanah-Tanah Muda (Regosol, Alluvial Dan Litosol). Soil Department, Agriculture Fakulty of Brawijaya University, Malang,

Sisworo, W. H. (2006). Swasembada Pangan dan Pertanian Berkelanjutan Tantangan Abad Dua Satu: Pendekatan ilmu tanah, tanaman dan pemanfaatan iptek nuklir, in Pirngadi (2009), Peran bahan organik dalam peningkatan produksi padi berkelanjutan mendukung ketahanan pangan nasional. Pengembangan Inovasi Pertanian 2(1), 48-64.

Tisdale, S. L., Nelson, \& Beaton, J. D. (1985). Soil Fertility and Fertilizers. Macmillan Pub. New York.

Wiyanti and Arya, I. N. G. (2008). Keberimbangan Pemberian Pupuk Organik dan Anorganik terhadap Pertumbuhan dan Hasil Padi di Lahan Sawah. Agritrop 27(4), 168 - 173. 